\title{
Literature Review on Diversification Strategy, Enterprise Core Competence and Enterprise Performance
}

\author{
Han Le \\ School of Business Administration, South China University of Technology, Guangzhou, China \\ Email: lehan1994@163.com
}

How to cite this paper: Le, H. (2019) Literature Review on Diversification Strategy, Enterprise Core Competence and Enterprise Performance. American Journal of Industrial and Business Management, 9 , 91-108.

https://doi.org/10.4236/ajibm.2019.91008

Received: December 20, 2018

Accepted: January 8, 2019

Published: January 11, 2019

Copyright $\odot 2019$ by author(s) and Scientific Research Publishing Inc. This work is licensed under the Creative Commons Attribution International License (CC BY 4.0).

http://creativecommons.org/licenses/by/4.0/

\section{c) (i) Open Access}

\begin{abstract}
Diversification is a strategic choice for enterprise expansion. Looking at the world, American companies in the 1960s and 1970s opened up a diversified path through large-scale mergers and acquisitions. However, by the 1980s and 1990s, American companies began to change from diversification to specialization, gradually returning to their main business, and the adjustment of this phenomenon made the performance of those companies significantly improved. Since then, how should companies abandon the choice of specialization and diversification strategy, and whether diversification is beneficial or unfavorable to corporate performance have become topics that domestic and foreign scholars are eager to study. Based on the concept, motivation and type of diversification strategy, this paper sorts out the relationship between corporate diversification strategy and corporate performance in domestic and foreign literatures. It is found that there is still no definitive answer to whether diversification strategy is beneficial to corporate performance. There are four different relationships: positive correlation, negative correlation and no significant correlation, and nonlinear correlation. The core competence of an enterprise is the fundamental support of diversified business operations and a deep-seated factor in the formulation and implementation of diversified business strategies. Research on the core competence of enterprises as a regulation or mediator of the relationship between diversification strategy and firm performance is still not perfect, and research in this field needs to be further explored.
\end{abstract}

\section{Keywords}

Diversification, Corporate Performance, Corporate Core Competence

\section{Introduction}

With the advancement of technology and the increasingly fierce competitive en- 
vironment, companies have begun to diversify their operations in order to reduce risks. Since the beginning of diversification in the 1920s, countries around the world have experienced many corporate diversification booms, and diversified operations have become an important model for the rapid expansion of some large companies. Especially in the 1960s and 1970s, some large companies in the United States set off a wave of big mergers and acquisitions, committed to rapidly expanding the company and diversifying the way through mergers and acquisitions and asset restructuring. So far, a comprehensive international group has emerged. Most of these groups have crossed regions, industries and markets, developing factories around the world, expanding their businesses, and making profits from various industries.

In 1982, Rumelt studied Fortune 500 companies and found that from 1949 to 1974 , the number of single or leading companies accounted from $70 \%$ to $37 \%$ of all companies, while the number of diversified companies rose from $30 \%$ to $63 \%$ [1]. However, during the fourth wave of mergers and acquisitions in the United States, that is, in the 1980s and 1990s, we found that most of the company's business restructuring priorities have changed significantly, and began to strengthen its leading business, which has divested those businesses that are not performing well or are not related to the dominant business. Some scholars have pointed out that by studying the business strategies of 100 large enterprises, more than half of the enterprises have completed "returning" and their business performance has been significantly improved [2].

At the same time, however, China has taken a diametrically opposite situation with the United States. Since the reform and opening up in the last century, Chinese companies have set off several waves of diversification. But decades of development have not brought spring to Chinese companies, and the results are not optimistic. For example, the Sanjiu Group and the Sun God Group have been fiercely defeated due to excessive diversification. In the late 1990s, most of China's enterprises re-adjusted their strategies and divested their side businesses that were not related to the main business, mainly to develop their main business, especially with the collapse of the Giant Group and Chunlan; this trend became more apparent. After the financial crisis in 2008, more and more enterprises in China are facing operational difficulties and need to make strategic adjustments in a timely manner. Therefore, what choices companies make between diversification strategies and normalization strategies is very important for the future development of enterprises.

At present, China is in the critical period of the wave of market economy reform, and enterprises play a key role as the "cell" of the national economy. Whether enterprises should implement diversification strategies in the end or how to implement diversified operations can improve the performance of enterprises is of great practical significance. This paper will summarize the relationship between diversified business strategy and corporate performance, and strive to find out the influencing factors and draw relevant conclusions. 


\section{The Review of the Concept, Motivation and Classification of Diversification Strategies}

\subsection{The Concept of Diversification Strategy}

Gort, an American scholar, first proposed the concept of diversification. Diversification refers to the increase of market heterogeneity of enterprise products. He emphasized that the so-called market heterogeneity is different from the nuance of the same product. It refers to cross-industry products or the business conduct of the service [3].

The term "diversity" first appeared in the 1950s. Ansoff, a famous American strategist and strategic management guru, published "Strategies for Diversification" in "Harvard Business Review" in 1957. In this article, he proposes the concept of diversification. He believes that diversification is a business strategy to develop new markets with new products, and is taken when the company develops to a certain stage for longer development and more profit.

At the same time, he believes that there are four directions for the growth of the company: one is to expand in the original market; the other is to sell new products in the empirical research on the relationship between diversification of the original market and the performance of the company; the third is to sell the original products in new markets different from the original market; the fourth is to develop new markets and sell new products. Among these four growth directions, he believes that the last direction is the so-called diversification [4]. For the first time, Ansoff clearly proposed the meaning of diversification strategy from the perspective of corporate growth strategy, and defined diversification with the increase of product categories. Since then, foreign scholars have done a lot of research on the performance of corporate diversification.

Then, in 1959, the British female scholar Penrose proposed that diversification is not only reflected in the increase in the number and variety of final products in the industry, but also in the vertical and vertical integration. The enterprise wants to develop new products to achieve diversification must be based on the original model. Great changes have been made in both production and distribution models [5]. We can see that Penrose believes that diversification is the diversification of different industries.

In 1962, corporate strategist Chandler elaborated on diversification from another perspective in "Strategy and Structure-The Historical Stage of American Industrial Enterprise Development" and proposed ways to improve the success rate of diversification through reform. Chandler conducted research on DuPont. He believes that the result of diversification is the increase of the final product line of the enterprise. Adjusting the organizational structure of the enterprise can improve the success rate of diversification. The organizational structure is adjusted with the adjustment of the enterprise strategy, and the transition from $\mathrm{U}$ to $\mathrm{M}[6]$.

In the same year, M. Gort Gault used quantitative analysis to study diversity in the book Diversification and Integration in American Industry. Gault believes 
that corporate diversification is the behavior of companies developing new markets that are different from the original ones, and the number of these new markets is gradually increasing. Gault believes that merely changing the production or integration of some products is not truly diversified. It can be seen that Gao Te's view is that diversification is significantly different from the original production market in terms of production methods, products, markets, and different industries [7]. Gort (1962) measured the degree of diversification based on SIC (Standard Industriai Ciassification), and conducted quantitative analysis on the diversified development of 111 large-scale manufacturing enterprises in the United States from 1947 to 1957. There are differences, electronic and chemical companies have the highest degree of diversification, petroleum and tobacco are the lowest; but there is no significant correlation between diversification strategy and economic performance.

Richard P. Rumelt Rummet's research on corporate diversification is a summary. He believes that different people define different diversity based on different research purposes, and he believes that diversity is through limited resources and Strength, carry out new activities related to the original activities [1]. From this we can see that Rumet's point of view is that new activities that are related to the original related activities are diversified. Through the analysis of the 1949-1969 American big business diversification strategy, he believes that related and dominant diversified enterprises perform best; the worst performance is non-related diversified and vertically integrated enterprises; due to the extension of core capabilities or The role of resource sharing, limited diversification to related industries will improve corporate performance, excessive diversification will reduce synergies and have a negative impact on corporate economic performance.

There are also scholars who try to explain pluralism through theories in other fields. From the perspective of resource-based theory, both product diversification and regional diversification are based on the process of heterogeneous economic organizations through asset utilization or asset development to achieve the goal of extending competitive advantage or enhancing competitive advantage. The study assumes that firms have specific advantages based on certain resources, but does not give a clear explanation of the factors of the environment in which the firm is located, especially institutional factors and specific advantages [8].

Industrial organization economics believes that diversified enterprises benefit from multiple types of coordination effects, such as the scope economy and economies of scale formed by the implementation of diversification strategies, the superiority of obtaining information from multiple product markets, and the obtaining of stable market returns as well as the way to find more efficient use of internal resources and sharing of knowledge and skills across business units [9].

In summary, there is no uniform definition of diversification for various research purposes and uncontroversy, or diversification is a business approach or 
a growth behavior. However, as can be seen from the above, diversification covers two aspects: one is an activity that has nothing to do with the original market and production, and the other is related to the original market and production but is new. The activities are also diversified.

\subsection{The Motivation of the Diversification Strategy}

In the market economy, the main reasons for enterprises to choose a diversification strategy are as follows: Firstly, to enhance competitiveness, through diversified operations, enterprises can obtain economies of scale, scope and market influence; secondly, diversify risks. The company can diversify non-systemic risks in its operations through a diversified business portfolio; thirdly, to maximize resource utilization, resources such as production capacity, knowledge management capabilities, and entrepreneurship can make huge gains in applications in different industries. However, in the process of diversification, there is inevitably the agency cost and the business risk of the enterprise [3].

Regarding the reasons for diversification, Ansoff summarized it into four categories: First, when the company cannot achieve its intended goal by virtue of its expansion strategy; second, the company has too much surplus, far exceeding the expansion needs; Third, the company has more than expansion strategy, when there are more profitable new market opportunities; Fourth, in the specific case, the prospects for expansion and diversification are uncertain [4].

In explaining the "diversity premium", Montgomery also made a distinction between the three major motivations for diversification strategies in 1994 [10]. First, the market forces view that companies are diversified not because they are more efficient but because they have acquired "group power". Diversification plays an important role in capturing market power. Diversified companies can reduce market competition and consolidate their predatory pricing through cross-subsidization, conspiracy, and reciprocal transactions, although this behavior will seriously harm consumers' interests [11]. The diversification strategy adopted by growth-oriented managers may make significant use of the scope economy while increasing the market power of the company. An effective way to increase the market power of the enterprise is Scott's multi-market linkage hypothesis [12]. Companies that compete in several markets have greater incentive to build networks to maintain their collective strength. In turn, multi-product companies can generate positive spillover effects through cross-subsidy activities, which means that the market strength and value of an industry's resources may increase due to investment in another industry [13]. Diversified companies benefit from multiple types of coordination effects, such as the economies of scale and economies of scale formed by companies implementing diversification strategies, the superiority of access to information from multiple product markets, and the achievement of stable market returns, as well as the effective use of internal resources, and sharing of knowledge and skills between pathways and business units [9]. 
According to the resource point of view, there will always be underutilized resources in the daily business activities of enterprises, that is, excess production factors, and the diversification strategy can help enterprises develop this part of redundant resources and realize the scope of economic effects through the sharing and transfer of resources. In order to reduce production and operation costs [14]. Therefore, the allocation of surplus resources and free cash flow are one of the main motives for diversification [15]. However, the asset characteristics of corporate resources create the sustainable competitiveness of the owner on the one hand, and the challenge on the other, hindering the company's ability to transfer resources to new applications or transplant them into a new environment [16]. Therefore, the value of diversification depends on the complementarity between the company's entry into internal resources and the company/industry, and the diversified model chosen. This opens the way for several empirical predictions of the relevance of diversified activities: the closer or more closely these activities are related, the more profitable the diversification expectations are.

In explaining the "diversity discount", the institutional perspective emphasizes the benefits that the company manager may sacrifice the interests of shareholders to get the benefits. The essence of diversification is the decision-making behavior of managers in order to seek their own hidden benefits and reduce their income risks, which will definitely damage corporate performance and company value. Considering that the diversification of large companies is due to the separation between ownership and control, the agency approach predicts a negative correlation between diversification and firm performance [17]. Hoskisson and Hitt [15] argue that diversification, firm size and executive compensation are highly correlated with the extent to which multilateralism does not provide economic benefits to investors.

In summary, scholars based on different interests, the interpretation of diversification motivation will be different, mainly to enhance competitiveness, reduce risks, optimize resource utilization, operators' own interests and appeals. However, the existing ideas are mainly derived from cases or theories. Future research can try to further explore the reasons for diversification from data analysis or rooted methods.

\subsection{The Classification of Diversification Strategies}

In the study of diversification strategy, how to divide the type of diversification strategy is a fundamental issue in the research of diversification strategy. Many researchers at home and abroad have made many different categories of classification, such as: Wrigley category method, Rumelt category method, Ansoff category method and so on.

Diversification of diversification strategies can generally be divided into two categories: related diversification and non-related diversification. One is related to diversity and the other is irrelevant. Related diversification can also be called concentric diversification, which refers to the choice of a new product or market 
area of an enterprise based on its existing business or market. Compared with non-related diversification, relevant diversification is conducive to giving full play to the company's original expertise, proprietary skills, marketing channels and other advantages, and the integration risk is small.

Non-related diversification, also known as centrifugal diversification, refers to the fact that the newly entered products or markets have no obvious strategic adaptability to existing businesses or markets. The added products are new products, and the market entering is a new market. It can be seen that the adoption of non-relevant diversification strategies by enterprises is not based on the common considerations of the company's original expertise, know-how, marketing channels, etc. The main motivation is to balance cash flow or obtain new profit growth points. Compared with the relevant diversification strategy, the implementation of non-related diversification strategies by enterprises has always been regarded as an extremely dangerous strategy by the academic community, because the implementation of non-related diversification strategies is generally accompanied by the expansion of business scope and the increase of business areas. Management risks that are difficult to manage. Enterprises should diversify their resources into an unfamiliar field and face new business-specific risks, laws and regulations, and special regulatory risks of regulatory authorities. Enterprises must invest hugely in the process of developing new fields. The human and material resources will inevitably affect the cultivation and development of the original core competitiveness, and bring the risk of the decline of core competitiveness. In addition, the implementation of the non-related diversification strategy is accompanied by the possibility of increasing financial risks.

In 1970, L. Wrigley completed his doctoral thesis "Business System and Diversification" at Harvard Business School. He proposed the measurement method and type division of the degree of diversification, which took an important step in the research of corporate diversification [18]. Riley proposed to measure the diversification of a company's product by its proportion of sales, that is, the specialization ratio. Diversification is a concept corresponding to specialization. From the perspective of business conditions, the standard for distinguishing between the two is "the proportion of sales of certain products to the total sales of enterprises", and the product categories of certain products are classified according to the international standards, which calls Four-digit industry standard in the Industry Classification (ISIC).

Based on Wrigley's diversified strategy research, Rumelt considers the relevance of corporate business and proposes core related ratios and vertical ratios [1]. Their classification is based on two indicators: specialization rate (SR) and correlation rate (RR). The specialization rate refers to the proportion of the sales of the largest business project of the enterprise to the total sales of the enterprise. The correlation rate refers to the ratio of the sales of the largest group of business projects associated with the company to the total sales of the company. This 
is the classification of the famous American scholar Riley Rummett.

Ansoff proposes four types of diversification in Corporate Strategy [19]: horizontal diversification (pointing to develop new products for customers with similar customers); vertical integration; Concentric diversification (Diversification based on the original capabilities of the company can be subdivided into three categories: sales technology-related, sales-related and technology-related); Conglomerate diversification (pointing to unrelated multi-industry development). Ansoff believes that concentricity can be more profitable and less risky than hybrid diversification.

In summary, the above three classification methods have been widely recognized and applied by the academic community. We can see that the Wrigley category method and the Ansoff class method are different, but the kernel is consistent. The Rumelt classification rule gives a concrete numerical scale reference and is more scientific.

\section{The Review of the Relationship between Diversification Strategy and Corporate Performance}

\subsection{The Review of the Relationship between Diversification Degree and Firm Performance}

There are four main views on the relationship between diversification and company performance in foreign countries: first, the higher the degree of diversification, the more favorable the company's performance; second, the higher the degree of diversification, the more unfavorable to the improvement of company performance; third, the degree of diversification has little effect on company performance; fourth, there is a non-linear " $U$ " relationship between diversification and company performance.

On the plus side, in 1971, scholars Weston and ManSinghka used the Fortune 500 companies as the research object. First, they classified these companies. The study found that those diversified companies were higher in economic performance than other companies, and they showed a return on net assets, earnings per share growth rate and sales growth rate indicators [20]. In 1986, Varadarajan used the number of enterprise products as a measure of the degree of diversification. The study found that the higher the degree of diversification, the better the company's performance [21]. In 1988, CaPon and his colleagues studied the economic performance of diversified firms with the best economic performance in diversified firms [22]. In 1995, John and Ofek randomly selected 321 companies from 1986 to 1988, and found that unrelated diversified firms had higher excess returns [23]. Amit and Livnat conducted an empirical study of this relationship in 1988. The results show that diversification of purely financial purposes will reduce cash flow volatility and reduce operational risk [24]. Li and Kami (2010) found that diversification can form internal capital markets and reduce operating costs, thereby improving firm performance [25].

There are many studies that believe that the higher the degree of diversifica- 
tion, the more unfavorable the company's performance improvement. Lang and Stulz (1994) used the "franchise store method" to innovate the Tobin'Q value. The research concluded that the Tobin'Q value of diversified companies is lower than that of specialized enterprises, and the value created is relatively low [26]. Comment and Jarrel (1995) use the effect of diversification on stock price returns as a research method, and find that the higher the degree of diversification, the lower the return rate of stock prices [27]. In the same year, Berger and Ofek selected 3,659 companies from 1986 to 1991 in the United States for research. Diversified operations had a "discount effect" and the effect of unrelated diversification was the greatest [23]. In 2002, John A. Doukas, Martin Holmen, Nicolaos G. Travlos discovered through research on 101 companies in Sweden that mergers and acquisitions of companies that are not related to the original industry will result in a decline in the business performance of the acquirer, and mergers and acquisitions. Industries that are consistent or related to the original industry will increase the benefits of the acquirer. And in the research, it is concluded that investing in unrelated industries will increase agency costs and reduce operational efficiency, exceeding the benefits of diversification [28]. Lialunga studied the diversification of Compusta enterprises from 1989 to 1996 and found that there are diversified discounts [29]. Li Benberg's empirical analysis of the US property insurance industry shows that the performance of specialized business companies is better than that of diversified operations [30].

Some scholars have also found that the degree of diversification has little effect on company performance. Gort (1962) selected 111 data from 1947 to 1957 in the United States, indicating that there is no correlation between corporate diversification and corporate performance indicators [7]. Ravenscraft (1983) used the Herfindahl index as a measure of the degree of diversification, and concluded that the relationship between the Herfindahl index and the company's marginal gross profit margin is not obvious [31].

Montgomery (1985) selected 128 companies in the Fortune 500 to conduct research, and concluded that companies with higher diversification have lower returns on investment than companies with low diversification. However, under the control of industrial factors, this relationship is not obviously, the diversification factor has not had an impact [32]. Ferris et al. (2002) also pointed out that diversified companies should develop diversified operations based on different resources and growth opportunities. Therefore, the impact of diversification on company performance is not absolute [33].

At the same time, a few scholars have found that there is a " $U$ " relationship between diversification and corporate performance. Markides (1995) pointed out that statistical analysis. Any enterprise has an optimal diversification level, and the enterprise performance and diversification level are inverted U-shaped [34]. The findings of Palich, Cardinal, and Miller (2000) are generally consistent with Markides (1995) [35].

The conclusions of domestic research are roughly equivalent to those of for- 
eign countries, and they are mainly divided into the above four viewpoints. In 2005, the famous Chinese scholar Su Dongwei studied the listed companies in China from 2001 to 2002, and found that the internal market of listed companies in China, especially the capital market, is more effective than the external market, and diversified enterprises. Has a higher excess value and Tobin'Q [36]. In the same year, Fu Jibo and Yang Chaojun used 680 listed companies in Shanghai as samples. The same result table diversified to create value from the higher asset-liability ratio of diversified enterprises and increased corporate value [37].

In 2006, Jiang Fuxiu, Liu Zhiwei, and Lu Zhengfei favored diversification because they believed that diversification and diversification risk and common corporate debt were incomparable [38]. Wang Lei (2009) believes that moderate diversification can make effective use of the remaining resources of enterprises and improve the efficiency of resource utilization [39]. Zhou Jinhua and Ji Hanlin (2015) analyzed this from different perspectives and thought that the phenomenon of diversification discount may be from the whole market, but the conclusion is not necessarily established in a specific industry, such as computer application service industry [3].

Second is the research aspect of diversification negatively affecting company performance. Yuan Fang's research using regression analysis in 2001 found that the improvement of diversification did reduce the performance of enterprises [40], and he studied with Zhang Weiguo and Chen Yu in 2002, and selected 72 listed companies in Shanghai and Shenzhen. They also achieved the same results, and pointed out that it is necessary to follow the relevant diversification path, appropriately establish an organizational structure that adapts to the company's strategic adjustment, and change the diversified businesses in a timely manner [41]. Hong Daolin and Xiong Dehua (2006) consider the impact of diversification on company performance from the perspective of company endogenous, and have an impact on diversification in corporate endogenous issues, and diversification will further damage corporate performance, even within the control of the company. In the case of problems, diversification has further weakened the company's performance [42]. Zhao Feng et al. (2016) conducted a survey of 191 samples randomly selected from enterprises in various industries in Shanghai in 2008-2009, and explored and tested the relationship between diversification strategy and corporate performance. The conclusion that corporate performance has a significant negative impact [43].

As for the relationship research between the two is not obvious. In 1995, Liu Li found that the degree of diversification of enterprises in his research sample had no correlation with corporate performance, and that the diversification of economic performance and the ability to improve corporate debt were not verified [44]. The regression analysis conducted by Zhu Jiang (1999) in the study of 146 listed companies also found that there is no significant influence on diversification and company performance [45]. Yao Jun, Lu Yuan and Lan Hailin selected 593 listed companies in Shanghai and Shenzhen from 1999 to 2001 in the 
same period in 2004, which also received the same answer as Zhu Jiang [46]. Qin Zheng et al. (2004) studied the relationship between diversification and financial performance, and divided 57 sample companies into three groups according to the degree of diversification. The results showed that the relationship between diversification and sales profit rate and total return on assets was not obvious [47].

Finally, Zheng Hua and Wei Xiaoke (2008) conducted an empirical study by means of research. The results show that there is a " $U$ " relationship between the degree of diversification and corporate performance, that is, when the diversification reaches a certain point, the enterprise has the greatest performance, both sides Corporate performance declines [48].

In summary, scholars use data from different countries and data from different industries to conduct research on the relationship between diversification and corporate performance. This helps us understand the differences between the degree of diversification and firm performance in a different economic and cultural context. However, these scholars did not point out the specific reasons for such differential results, nor did they explore the influencing factors, which are very important in our process of defining the relationship between diversification and firm performance.

\subsection{The Review of the Relationship between Diversified Types and Firm Performance}

Looking at domestic and foreign research data on the impact of diversification types on company performance, we can find that there are few research results in this area, and from the conclusions drawn, the economic performance of related diversified enterprises is generally better than that of unrelated diversified enterprises.

Rumelt (1974) selected 246 of the Fortune 500 companies and completed the classification of these enterprises, which were divided into four types of diversification. The diversification of related business-oriented enterprises will improve the company's performance, while the excessive diversification of non-business-related enterprises will reduce the company's performance [1]. Michel and Shaked (1984) followed the Rumelt classification and selected professional ratios, vertical ratios, and correlation ratios as a measure of the degree of diversification. The study concluded that the performance of non-related diversified businesses is higher than that of related diversified businesses. This is contrary to Rumelt's research [49].

Diversified companies need to introduce a suitable organizational structure to support the implementation of diversification strategies and improve corporate performance. The $\mathrm{M}$-form is an organizational structure suitable for diversified strategic development, and most foreign studies confirm that diversified businesses that implement business divisions are related to performance. Armour and Teece concluded through an empirical study of 27 oil companies in the United States from 1955 to 1973 that there was a positive correlation between 
M-form structure and ROE in the transition to M-form [50]. Hoskisson and Galbraith conducted a time series analysis of six companies in three industries, and concluded that the adoption of $\mathrm{M}$-form is positively correlated with performance [51]. Hoskisson et al. used the data of the capital market to evaluate the application effect of $\mathrm{M}$-form on diversified enterprises. The adoption of $\mathrm{M}$-form by investors is certain, that is, $\mathrm{M}$-form can improve the performance of diversified enterprises [52]. Research by Lamont et al. also confirms that the divisional system is indeed a structural form that matches the diversification strategy [53].

In domestic research, Yin Yisheng used the theory of enterprise growth in 1998 to conduct empirical research on diversified types and company performance, and reached several conclusions: 1) From the perspective of the degree of diversified business operations in China and abroad, the degree of diversification in China Less than foreign companies; 2) Unrelated diversified enterprises can weaken the risk of market return rate weakly, but the intensity is small; 3) Relevant diversified enterprises can increase the sales growth rate of enterprises; 4) Unrelated diversified enterprises will increase Corporate liabilities [52]. In 2001, Yin Yi used data from 126 listed companies in Shanghai and Shenzhen from 1995 to 1996. The research concluded that the economic performance of specialized enterprises and related diversified enterprises is better than that of unrelated diversified enterprises. Accordingly, Business risks are reduced [54]. In 2002, Li Jing cited Rumelt's classification method to conduct empirical research on 105 listed companies in China. Diversification will reduce the company's economic performance, and the performance of implementing unrelated diversified enterprises is significantly lower than that of specialized enterprises and related diversification enterprises, and this is consistent with Yin's research conclusions [55].

At present, the organizational structure of diversified enterprises in China also presents diversified characteristics. From U-form (functional type) to $\mathrm{H}$-form (mother-child company system) and M-form (business department system), there are many enterprises. This shows that Chinese enterprises have not learned from the experience of foreign countries in the choice of organizational structure, and have reservations about the departmental system. A large number of foreign empirical studies have proved that $\mathrm{U}$-form and $\mathrm{H}$-form are not suitable for diversified organizational structure. Zhao Feng, Wang Tienan, and Zhang Liang (2012) put forward the hypothesis in this study: the performance of diversified enterprises using M-form is better than that of other organizational types, and this is confirmed [43].

The analysis of the relationship between different types of diversification strategies and corporate performance can, to a certain extent, clarify the role of different types of diversification strategies in different types of enterprises and countries. However, these studies are more simply to compare the differences between different types of diversified and different organizational structures, and have not studied the causes and influencing factors, which deserves further supplement and improvement. 


\section{The Review of the Diversification Strategy, Core Competence of Enterprises and Performance of Enterprises}

In 1990, CK Prahaad and G. Hamei proposed the concept of "enterprise core competence", arguing that the core competence of the enterprise is "the accumulation of knowledge in the organization, especially the knowledge about how to coordinate different production skills and organically combine multiple technical flows" [56]. Chen Zhijun (2005) extracted the understanding of the core competence of the enterprise, and believed that the enterprise is essentially a combination of knowledge and ability, and the growth of ability is not a one-off event. It is a process of continuous accumulation, the core of the enterprise. Capability is not a single ability, but an organic combination of multiple capabilities. Its growth is a process of mutual synergy and integration between multiple capabilities. At the same time, the success of the diversification strategy depends on the core competence and the diversified business matching mismatch, and the core competence is immature [57].

Wang Jiang (2007) based on the views of Prahalad and Hamel, proposed that the core competence of enterprises is the basis of diversified business, and that diversified enterprises should be a combination of core competences, not products and undertakings in the traditional sense. The combination, from the perspective of the company's development strategy, the so-called "diversification" or "centralization" is only a formal problem, in essence, it is the core competence of the enterprise [58].

Cao Yanai (2009) believes that enterprises choose to implement diversification strategy or specialization strategy mainly depends on the productivity and flexibility of the core competence of the enterprise. That is, when the core competence of the enterprise is strong and the elasticity is poor, the enterprise should adopt specialization or related diversity strategies. When the core competence of the enterprise is strong and its elasticity is good, the enterprise can choose one of the specialization strategies, related diversification strategies and non-related diversification strategies [59]. This also affirms the guiding position of the core competence of enterprises in the choice of diversified strategies.

Wang Yu (2009) summarized that the impact of diversification on core competitiveness is mainly reflected in the following aspects: the remaining resources of enterprise management, the transferability of existing core competitiveness of enterprises, and the transferability of the core competitiveness that the enterprise will develop from the existing industry to the target industry. At the same time, it is considered that the core competitiveness is the soul of diversification. The diversified development of the enterprise must be centered on the core competitiveness to be successful, and the core competitiveness of the enterprise is studied as a mediator of diversification and corporate performance [60]. Sun Lei (2005) also believes that diversified management should be based on core competitiveness based on previous studies. The application and expansion of core competitiveness must be realized by diversified management. The core 
competitiveness of enterprises is the essence of diversification strategy [61].

Wang Yanqing (2014) also recognizes that core competence is the internal dependence and foundation of diversified operations, and believes that diversified operations strengthen core competencies. Diversified operations and core competencies should be organically integrated, integrated, and developed based on core competencies. Diversified management can effectively diversify risks, obtain scope economic benefits, and better promote the long-term development of enterprises [62].

$\mathrm{Xu}$ Juan (2016) based on the core technology capability theory, constructed a theoretical model of the diversification of related technologies and the diversification of unrelated technologies through the intermediary variables of the core technical capabilities of enterprises, and considered the different levels of core technology capabilities. The adjustment effect in the process of enterprise competitiveness, the relationship between the three is studied from the technical level of core competence [63]. In addition, many scholars have studied the relationship between diversification strategy and core competence of enterprises in specific industries such as tourism, real estate, and medicine, as well as private enterprises and small and medium-sized enterprises.

In summary, we can conclude that the core competence of an enterprise is the fundamental support of diversified business, the premise of the success of diversified business, and an important factor affecting the relationship between diversification and corporate performance. However, most of the research focuses on the single relationship between diversification and core competencies, diversification and corporate performance, or core competencies and corporate performance. A few articles on the relationship between the three are only started from a small scope, or only theoretical derivation and elaboration, which provides us with a perfect space.

\section{Conclusions}

Based on the above research, there is no unified consensus on the relationship between diversification strategy and corporate performance. There are five main viewpoints: 1) The degree of diversification has a "premium effect" on corporate performance. The higher the degree of diversification, the more favorable it is. 2) The degree of diversification has a "discount effect" on corporate performance. The higher the degree of diversification, the more unfavorable it is to the improvement of corporate performance. 3) The degree of diversification has no obvious impact on corporate performance. 4) The degree of diversification has a nonlinear relationship with corporate performance. 5) The economic performance of related diversified enterprises is better than that of unrelated diversified enterprises.

Diversification is a strategic choice made by an enterprise after comprehensively measuring its resources and capabilities. Therefore, how strong or weak the core competence of the enterprise can play a central role in the diversified 
field will inevitably affect the decision-making and corporate performance of the company. The core competence of an enterprise is the organic integration of the multi-faceted skills of the enterprise and the operational mechanism of the enterprise, and is the synergy of the competitiveness and competitive advantage of the enterprise in a specific business environment. What are the specific aspects of the core competencies of the enterprise, what impact they have on the relationship between diversification and corporate performance, and how the company can make strategic choices based on the core competencies of the enterprise to ensure the performance of the company, have yet to be explored.

\section{Inadequacies and Future Prospects}

This paper reviews the relationship between diversification strategy and corporate performance, mainly expounds the concept, reason and classification of diversification, as well as the different influences of diversification and different types on corporate performance, and the adjustment of corporate core competence. A separate statement has laid a foundation for future diversification research. However, due to the limitations of literature reading and the lack of authors, this paper is not perfect enough to understand the academic viewpoints. The generalization and discussion are relatively simple. In the future, the literature review in this field can be continuously expanded and improved with the deep research of scholars.

\section{Conflicts of Interest}

The author declares no conflicts of interest regarding the publication of this paper.

\section{References}

[1] Rumelt, R.P. (1974) Strategy, Structure and Economic Performance. Harvard University, Boston.

[2] Zhou, Y.D. (2004) Diversified Business Strategy and Empirical Research on Corporate Performance. Jinan University, Guangzhou.

[3] Zhou, J.H. and Ji, H.L. (2015) An Empirical Study on Diversified Management and Business Performance of Enterprises. Reform and Open, No. 22, 25-26, 28.

[4] Ansoff, H.I. (1957) Diversification Strategy. Harvard Business Review.

[5] Penrose, E.T. (1959) The Theory of the Growth of the Firm. New York.

[6] Chandler Jr., A.D. (1962) Strategy and Structure. Chapter in the History of the Industrial Enterprise. MIT Press, Cambridge.

[7] Gort, M. (1962) Diversification and Integration in American. Princeton University Press, Princeton, New Jersey.

[8] Song, T.B., Lan, H.L. and Zeng, P. (2010) Regional Diversification or Product Diversification: Strategic Choice of Dominant Enterprises under the Constraints of Institutional Environment. Journal of Guangzhou University: Social Science Edition, No. 3, 45-52.

[9] Zhou, Q., Xie, S.-L. and Liu, F. (2014) Organizational Structure and Firm Perfor- 
mance of Diversified Firms-Based on Research in Sichuan and Chongqing. Journal of Chongqing Jiaotong University (Social Science Edition), No. 5, 51-54.

[10] Montgomery, C.A. (1994) Corporate Diversification. Journal of Economic Perspectives, 8, 163-178. https://doi.org/10.1257/jep.8.3.163

[11] Berry, C.H. (1971) Corporate Growth and Diversification. The Journal of Law and Economics, 14, 371-383. https://doi.org/10.1086/466714

[12] Scott, J.T. (1993) Purposive Diversification and Economic Performance. Cambridge Books, No. 3, 342-345. https://doi.org/10.1017/CBO9780511528439

[13] Foss, N.J. and Christensen, J.F. (2001) A Market-Process Approach to Corporate Coherence. Managerial \& Decision Economics, 22, 213-226. https://doi.org/10.1002/mde.1012

[14] Penrose, E.T. (1995) The Theory of the Growth of the Firm. Oxford University Press, Oxford. https://doi.org/10.1093/0198289774.001.0001

[15] Hoskisson, R.E. and Hitt, M.A. (1990) Antecedents and Performance Outcomes of Diversification: A Review and Critique of Theoretical Perspectives. Journal of Management, 16, 461-509. https://doi.org/10.1177/014920639001600210

[16] Montgomery, C.A. and Wernerfelt, B. (1988) Diversification, Ricardian Rents, and Tobin's Q. Rand Journal of Economics, 19, 623-632. https://doi.org/10.2307/2555461

[17] Jensen, M.C. (1986) Agency Costs of Free Cash Flow, Corporate Finance, and Takeovers. The American Economic Review, 76, 323-329.

[18] Wrigley, L. (1970) Divisional Autonomy and Diversifieation. Unpublished Doetoral Dissertation, Harvard Business School, Boston.

[19] Ansoff (2009) New Company Strategy. Southwestern University of Finance and Economics Press.

[20] Weston, J.F. and ManSinghka, S.K. (1971) Tests of the Efficiency Performance of Conglomerate Firms. Journal of Finance, 34, 919-936.

https://doi.org/10.1111/j.1540-6261.1971.tb00928.x

[21] Varadarajan, P.R. and Ramanujam, V. (1986) Diversification and Performance: A Reexamination Using a New Two-Dimensional Conceptualization of Diversity in Firms. Academy of Management Journal, 30, 380-393.

[22] Capon, N. (1988) Corporate Diversity and Economic Performance: The Impact of Market Specialization. Strategic Management Journal, 9, 61-74. https://doi.org/10.1002/smj.4250090106

[23] John, B. and Ofek, P.G.E. (1995) Diversification's Effect on Firm Value. Journal of Economics, 37, 39-65.

[24] Amit, R. and Livant, J. (1988) Diversification Strategies, Business Cycles and Economic Performance. Strategic Management Journal, 9, 99-110. https://doi.org/10.1002/smj.4250090202

[25] Li, X.R. and Kami, R. (2010) Diversification and the Internal Capital Market Building Motive in China. Journal of Transnational Management, 15, 103-116. https://doi.org/10.1080/15475778.2010.481245

[26] Lang, I.H., Stulz, R.M. and Tobin, Q. (1994) Corporate Diversification and Firm Performance. Journal of Political Economy, 102, 1248-1280. https://doi.org/10.1086/261970

[27] Comment, R. and Jarrel, G. (1995) Corporate Focus and Stock Returns. Journal of Financial Economics, 37, 67-87. https://doi.org/10.1016/0304-405X(94)00777-X 
[28] Doukas, J.A., Holmen, M. and Travlos, N.G. (2002) Diversification, Ownership and Control of Swedish Corporations. European Financial Management, 3, 281-314.

[29] Villalonga, B. (2004) Diversification Discount or Premium New Evidence from the Business Information Tracking Series. Journal of Finance, 9, 479-506.

[30] Liebenberg, S. (2008) Effects of Corporate Diversification: Evidence from the Property Liability Insurance Industry. Journal of Risk and Insurance, 75, 893-919. https://doi.org/10.1111/j.1539-6975.2008.00290.x

[31] Ravenscraft, D. (1987) The 1980s Merger Wave: An Industrial Organization Perspective in the Merger Boom: An Overview. Federal Reserve Bank of Boston, Boston.

[32] Montgomery, C.A. (1982) The Measurement of Firm Diversification: Some New Empirical Evidence. Academy of Management Journal, 25, 299-307.

[33] Li, S. (2015) An Empirical Study on the Relationship between Diversified Business Level and Corporate Performance. Henan University, Kaifeng.

[34] Markides, C.C. (1995) Diversification, Restructuring and Economic Performance. Strategic Management Journal, 16, 101-118. https://doi.org/10.1002/smj.4250160203

[35] Palich, L.E., Cardinal, L.B. and Miller, C. (2000) Curvilinearity in the Diversification Performance Linkage: An Examination of Over Three Decades of Research. Strategic Management Journal, 21, 155-174. https://doi.org/10.1002/(SICI)1097-0266(200002)21:2<155::AID-SMJ82>3.0.CO;2-2

[36] Su, D. (2005) Diversified Management and Enterprise Value. An Empirical Study on the Diversified Premium of Listed Companies in China. Economic Quarterly, No. S1, 135-158.

[37] Fu, J. and Yang, C. (2005) Diversified Management and Corporate Value Research. Journal of Dalian University of Technology (Social Sciences Edition), No. 6, 28-33.

[38] Jiang, F., Liu, Z. and Lu, Z. (2006) Research on Diversified Management, Enterprise Value and Income Fluctuation. Research on Financial and Economic Issues, No. 11, 27-35.

[39] Wang, L. and Zhang, Q. (2009) Analysis of Self-Organization Evolution of Enterprise Knowledge Capabilities in Dynamic Environment. Library and Information Service, 53, 80-83.

[40] Yuan, F. (2001) Study on the Relationship between Diversification Strategy and Economic Performance of Enterprise Groups. Journal of Chongqing University (Social Science Edition), No. 1, 35-37.

[41] Zhang, W., Yuan, F. and Chen, Y. (2002) An Empirical Study on the Relationship between Diversified Strategy and Economic Performance of Listed Companies. Journal of Chongqing University, No. 11, 135-139.

[42] Hong, D., Liu, L. and Xiong, D. (2006) Diversified M\&A, Enterprise Long-Term Performance Loss and Its Choice Motivation. Economic Sciences, No. 5, 63-73.

[43] Zhao, F., Wang, T. and Zhang, L. (2012) An Empirical Study of the Impact of Diversification Strategy on Firm Performance. China Soft Science, No. 11, 111-122.

[44] Liu, L. (1995) Diversification and Its Impact on Corporate Value. Economic Science, No. 8, 68-74.

[45] Zhu, J. (1999) Diversified Strategy and Business Performance of China's Listed Companies. Economic Research, No. 11, 54-61.

[46] Yao, J., Lu, Y. and Lan, H. (2004) An Empirical Study on the Relationship between Diversification of Listed Companies and Economic Performance in China. Man- 
agement World, No. 11, 119-125+135.

[47] Qin, Z., Chen, S. and Zou, J. (2004) Diversified Management and Corporate Governance Structure of Chinese Listed Companies. Journal of Management, 1, 134-138.

[48] Zheng, H. and Wei, X. (2008) The Non-Linear Impact of Corporate Diversification Strategies on Performance. Productivity Research, 3, 126-127.

[49] Michel, A. and Shaked, I. (1984) Does Business Diversification Affect Performance? Finance Management, 13, 18-25.

[50] Armour, H.O. and Teece, D.J. (1978) Organizational Structure and Economics Performance: A Test of the Multidivisional Hypothesis. Bell Journal of Economics, 9 , 106-122. https://doi.org/10.2307/3003615

[51] Hoskisson, R.E. and Galbraith, C.S. (1985) The Effects of Quantum versus Incremental M-Form Reorganization on Performance: A Time Series Exploration of Intervention Dynamics. Journal of Management, 11, 55-70. https://doi.org/10.1177/014920638501100305

[52] Hoskisson, R.E., Harrison, J.S. and Dubofsky, D.A. (1991) Capital Market Evaluation of M-Form Implementation Strategy. Strategic Management Journal, 12, 271-279. https://doi.org/10.1002/smj.4250120403

[53] Lamont, B.T., Williams, R.J. and Hoffman, J.J. (1994) Performance during M-Form Reorganization and Recovery Time. Academy of Management Journal, 2, 153-166.

[54] Yin, Y. (1999) Moderately Diversified-Enterprise Growth and Business Restructuring. Sanlian Bookstore Press, Shanghai.

[55] Li, J. (2002) Diversification Strategy. Fudan University Press, Shanghai.

[56] Prahaiad, C.K. and Hamei, G. (1990) The Core Competence of the Corporation. Harvard Business Review, Brighton.

[57] Chen, Z. (2005) Corporate Diversification Strategy Choice Based on Core Competence Maturity-Also on the Success and Failure Factors of Haier's Diversification. Journal of Chongqing Technology and Business University, West Forum, No. 5, 97-100.

[58] Wang, J., Yang, X. and Fan, Z. (2001) The Core Competence of Enterprises and Its Relationship with Diversification Strategy. Industrial Engineering and Management, No. 1, 31-34.

[59] Cao, Y. (2009) Thoughts on Enterprise Diversification and Specialization Strategy Selection-Based on the Analysis of Enterprise Resource Capability Theory. Reformation and Strategy, 25, 46-49.

[60] Wang, Y. (2009) Research on the Relationship between Enterprise Diversification Degree and Performance Based on Core Competitiveness. Zhejiang University of Technology, Hangzhou.

[61] Sun, L. (2005) Research on Diversification Strategy of High-Tech Enterprises in China Based on Core Competence. Wuhan University of Technology, Wuhan.

[62] Wang, Y. (2014) Analysis of the Causes and Countermeasures of the Failure of Diversification Strategy Based on Core Competence. China Management Informationization, No. 1, 104-105.

[63] Xu, J. (2016) Technology Diversification, Core Technology Capabilities and Firm Performance-Panel Data from Listed Companies in New Energy Automobile Industry. Economic Management, 38, 74-88. 